\title{
Poskus branja zgodovine kulturne krajine na Krasu An Attempt to read the History of the Karst Cultural Landscape
}

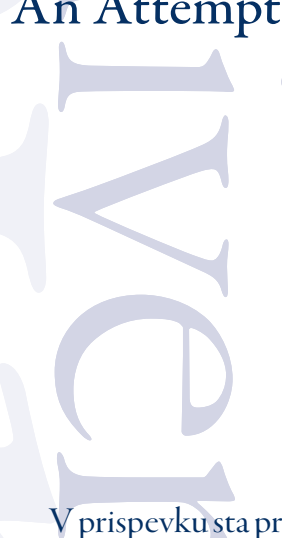

V prispevku sta predstavljeni analiza in interpretacija posnetkov lidar površja slovenskega Krasa. Ugotovljeni so bile različne oblike in vzorci parcelacij, domnevno iz obdobja prazgodovine in antike. Ti so bili razvrščeni v skupine glede na obliko parcel in načina delitve zemlje. Narejen je bil poskus predstavitve njihovega sosledja ter s tem rekonstrukcija nastanka in razvoja kulturne krajine.

Ključne besede: LiDAR, parcelacija, kulturna krajina, Kras, gradišča, prazgodovina, antika

The research paper contains an analysis and interpretation of LiDAR images and data showing different areas of the Slovene Karst region. The images show different shapes and patterns of land (field, parcel) division in this area which probably date from prehistory and antiquity. They have been divided into groups based on the shape of the parcel and method of field division. The paper also attempts to chronologically sequence them and thus reconstruct the beginning and the evolution of cultural landscaping in the aforementioned area.

Keywords: LiDAR, field divison, cultural landscape, Karst, hilltop settlements, prehistory, antiquity

P rispevek je poskus prepoznavanja in razvrstitve različnih oblik parcelacije iz preteklosti, domnevno iz prazgodovine in anti$\mathrm{ke}$, in s tem ustvariti prostor za interpretacijo ter globlje razumevanje vzorcev in zakonitosti oblikovanja kulturne krajine in rabe prostora. Obdelana je bila širša okolica Komna s posameznimi primeri z ostalega Krasa. V prispevku so prikazani le izseki, ki bolje predstavljajo oblike in vzorce parcelacije, ki pa se pojavljajo povsod na Krasu. Prav ponavljanje sledov enakih oblik in vzorcev delitve zemlje v različnih kontekstih se razume kot potrditev njihove verodostojnosti.

Kras je pretežno med 200 in $400 \mathrm{~m}$ visoka apnenčasta planota, ki je s treh strani ostro zamejena. Strmo se spušča proti Tržaškemu zalivu na jugu in proti Vipavski dolini na severu, kjer jo obroblja venec hribov, visokih do $600 \mathrm{~m}$. Nekoliko blažji je spust v Furlansko nižino na za- hodu. Manj izrazito je zamejena na vzhodu, kjer prehaja v gričevnato-hribovite Brkine. Po sredini Krasa niz vzpetin deli planoto v dinarski smeri JV-SZ na dva dela, po njih sedaj teče državna meja z Italijo.

Na Krasu je bilo treba v pridobitev obdelovalne površine vložiti veliko dela - otrebiti kamenje na površini ter razbiti/lomiti skale, ki so štrlele iz tal. Iz zemeljskih žepov med skalami pa se je kopala prst in se nanašala tja, kjer je je primanjkovalo. Izpraznjeni žepi so bili zravnani s kamenjem in prekriti s prstjo. Do obdelovalne zemlje in pokrajine, kakršno poznamo danes, je vodila dolga pot. Opravljena je bila postopno, sledile so si (in si še) izboljšave, ki so bile v skla$\mathrm{du} z$ danostmi in tudi zmožnostmi/potrebami obdelovalne tehnologije. Težko pridobljeno obdelovalno zemljo je bilo treba zaščititi pred živino in burjo, zato so jo obdali s suhozidi. Nagnje- 


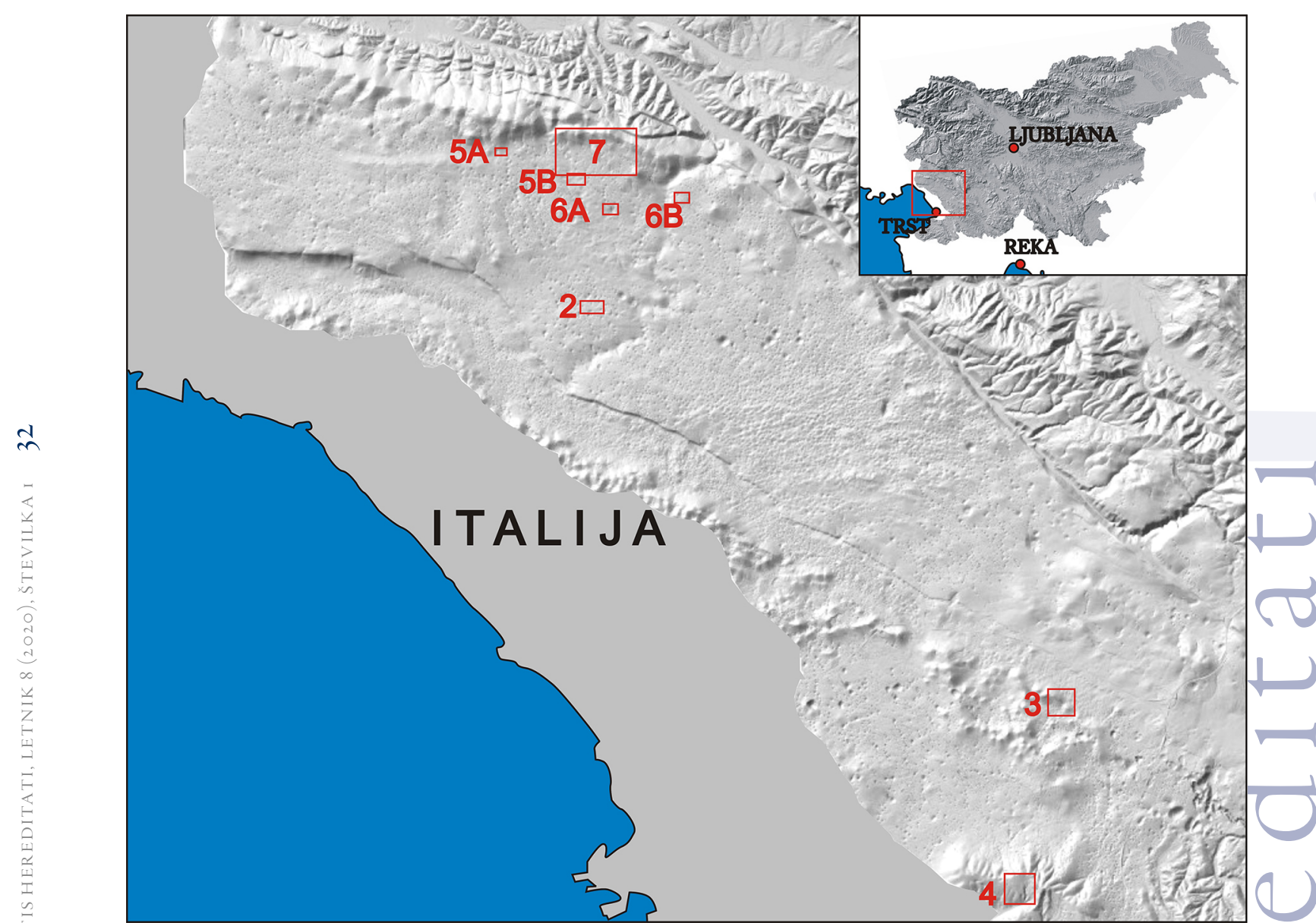

LEGENDA:

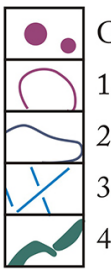

Groblje

1. parcelacija -ovalna polja

2. parcelacija -polja organskih oblik

3. parcelacija -polja $z$ ravnimi stranicami

4. Parcelacija -polja $z$ nepravilnimi stranicami

Slika i: Slovenski kras z označenimi izseki obravnavanih območij.

ni tereni so bili izravnani v terase (Panjek 20I5, 47-53).

Kot je znano, je območje doživelo dva poselitvena in civilizacijska vala. Prvi, tj. staroveški, se začne $\mathrm{z}$ mlajšo kameno dobo, konča pa z zatonom Rima. Drugi ciklus, ki še traja, pa se je začel s srednjim vekom. V prispevku se osredoto- čam na parcelacijo, pripisano prvemu ciklusu, ob strani pa puščam domnevne srednjeveške in novoveške posege.

\section{Metodologija}

Obliko polj na Krasu velikokrat narekuje razgiban teren, npr. vzpetine, na njih plastnice, predvsem pa vrtače s svojo ovalno obliko. Opažanja so se $\mathrm{v}$ prvi vrsti osredotočila na primere, pri katerih je bila za obliko parcel odločilna predvsem volja človeka. Kjer oblik parcel ne narekuje oblika površja, se predpostavlja, da gre za oblike deljenja, parceliranja zemlje, ki so bile v rabi v preteklosti.

Glavni vir podatkov so posnetki zračnega laserskega skeniranja tal (Mlekuž 20II, 87-IO4) objavljeni na spletni strani Ministrstva za oko- 
lje in prostor ter na strani PISO - Prostorski informacijski sistem občin. Posnetki niso bili dodatno obdelani, temveč uporabljeni v navadnem sivinskem senčenju terena. $\mathrm{V}$ nekaterih izbranih točkah je bil opravljen tudi ogled na terenu. Predvsem pri prepoznavanju sledov tretje parcelacije $\mathrm{z}$ ravnimi linijami so bile zaradi podobnosti s posegi v prostor iz 19. stoletja opravljene preverbe $\mathrm{v}$ franciscejskem katastru.

Pri parcelnih mejah so bili sprva upoštevani le sledovi, ki niso povezani z današnjo parcelacijo in se navezujejo na gradišča ter znane rimske ostaline. Ti so najjasnejši in najštevilnejši na predelih, ki v novem veku niso služili kot obdelovalne površine, temveč kot gozd, travniki in predvsem pašniki. Meje polj in njihova notranja ureditev so na posnetkih lidar opazni bodisi kot izstopajoči zidovi ali škarpe, največkrat pa zaradi sesutja le-teh kot nasipi. Lahko so tudi zamejena $s$ potmi. Pojem polje se uporablja v smislu posamezne parcele, največkrat ograjene z zidom. Poti so povečini opazne kot $\mathrm{v}$ teren vdrte črte, sledi, če so bile obrobljene $\mathrm{z}$ zidovi, pa kot dva vzporedna nasipa (Mlekuž 20I5, 68I).

Opaženo je bilo, da se vzorci, ki so značilni za oblike parcelacije prvega civilizacijskega ciklusa, pojavljajo tudi v sodobni parcelaciji. V nadaljevanju raziskave se je pokazalo, da je smiselno upoštevati tudi dele sedanjih parcelnih mej, predvsem tiste, ki se navezujejo na potek starih, opuščenih struktur in zidov, ter tistih, ki so jim po obliki sorodni.

Beleženje sledov stare parcelacije je bilo opravljeno z izrisovanjem preko posnetkov lidar. Zidovi so bili izrisani s črtami, ki so le v primerih masivnejših nasipov odebeljene in sledijo obrisu. $\mathrm{V}$ primeru tretje parcelacije so bile pri izrisovanju skoraj dosledno uporabljane ravne črte, kljub nekoliko drugačnemu stanju v naravi. Vzrok za to je spoznanje, da so bile pri tej obliki parcelacije prav ravne črte osnovno sredstvo za deljenje zemlje. Vzrok za nepravilnosti so lahko kasnejše spremembe, nastale morda s sesipanjem zidov in škarp ter $\mathrm{z}$ njihovimi popravili, in nedosledna

Http://gis.arso.gov.si/evode/profile.aspx?id=atlas_voda_Lidar@ Arso. vzpostavitev ravnih črt v naravi. To je še posebej opazno, ko se je ta oblika parcelacije prilagajala predhodnim. Pri tej obliki so se sistematično uporabljale tudi vzporedne črte. Ta ugotovitev se je upoštevala tudi pri izrisovanju sledi. Pri tem so bile upoštevane tudi manj izrazite in osamljene sledi, ki jih kot posameznih ne bi bilo možno upoštevati. Verodostojnost jim daje ponavljanje enakih vzorcev in zakonitosti. Sem prištevamo tudi nekatere elemente domnevno naravnega reliefa, npr. plastnice. Te so bile upoštevane le, če so se vklapljale v kontekst določene parcelacije ${ }^{2}$.

Groblje so povečini izrisane okroglo, četudi to niso. Okrogla je domnevno njihova izvorna oblika. Kraševci so starejše groblje in kupe kamenja pri čiščenju polj in travnikov pogosto uporabljali za odlaganje kamenja in s tem spreminjali njihovo prvotno obliko.

Da je določena sled stara, je mogoče sklepati iz konteksta. Predvsem po tem, da se navezuje na stare strukture (npr. gradišča), na staro opuščeno parcelacijo in da je presekana s kasnejšimi, sedanjimi, strukturami pa tudi po tem, ali po obliki spada $\mathrm{v}$ katero od predlaganih skupin parcelacije. V primeru poti je to mogoče sklepati tudi po tem, da se na posameznih odsekih pojavljajo deli starejših vzporednih tras.

Glede na obliko so bila polja razdeljena v štiri skupine. Te so: ovalna polja, polja organskih oblik, polja z ravnimi stranicami ter polja z nepravilnimi stranicami. Vsaka uporablja povsem svoje oblike in logiko deljenja zemlje. Časovno umeščanje posamezne oblike parcelacije je domneva, ki temelji na sorodnosti in odnosu z gradišči in s poznanimi rimskimi ostalinami ter glede na medsebojne odnose. Glede na pojavljajoče se vzorce in odnose z oblikami parcelacij je mogoče domnevati njihovo sosledje in razvoj. Glede na pojavljanje vzorcev, značilnih za parcelacije v starem veku znotraj konteksta sodobne parcelacije, smemo domnevati na kontinuiteto, na neprekinjeno in ponovno uporabo starejših struktur. Posamezna parcelna meja, zid, pripadajoč starej-

\footnotetext{
Človek je svoje posege vedno prilagajal naravnem reliefu in tega svojim posegom. Plastnice, ki so bile upoštevane, po vsej verjetnosti niso povsem $\gg$ naravne $\ll$ in za celotno interpretacijo niti niso odločilne.
} 
ši obliki parcelacij, je v kasnejšem obdobju lahko še v celoti ali pa le delno v uporabi.

Vzrokov za to je lahko več. Prvi bi lahko bil lastništvo. Zaradi različnega lastništva meja ni bilo mogoče spreminjati. Drugi bi bil razgibanost terena in potrebno delo. Spreminjanje mej in regulacija se zaradi prevelikega vložka dela enostavno nista splačala, zato se je tudi v večji ali manjši meri ohranila starejša poljska razdelitev.

\section{Rezultati}

\section{Prva parcelacija - ovalna polja ${ }^{3}$}

Prva oblika parcelacije so verjetno posamezna ovalna polja. Opazni so številni sledovi takih polj. Pogosto so komaj vidni in komaj izstopajo iz terena. Polja so najpogosteje ohranjena le delno, njihovi deli so včasih vključeni v katero od kasnejših oblik parcelacije, lahko tudi v sedanjo parcelacijo. To opažamo predvsem na kamnitejših in bolj razgibanih predelih, slutiti pa jih je tudi znotraj gradišč in sedanjih vasi (o tem več $\mathrm{v}$ nadaljevanju). Prav številčnost njihovih sledov in vseprisotnost njihovih delov $\mathrm{v}$ vseh drugih, kasnejših, oblikah parcelacije navaja $\mathrm{k}$ domnevi o prvobitnosti te oblike parcelacije.

Z gradnjo ovalne ograde se z najkrajšim zidom zaobjame največja površina zemlje. Razmerje med vloženim delom in pridobljeno obdelovalno površino je najugodnejše. To je smiselno, dokler je razpoložljivih površin še na pretek. Vtis je, da površina znotraj polj v tej fazi ni bila bistveno izboljšana. Na kamnitih terenih lahko znotraj ograd vidimo skale in kamenje, na nagnjenih površinah površina ni izravnana v terase. Ovalna polja so bila morda v uporabi že pred nastankom gradišč in v njihovi začetni fazi. Ostanke ovalnih polj najdemo po celotnem ozemlju, kjer jih ni uničila kasnejša obdelava zemlje. Število in morda tudi površina ovalnih polj sta se skozi čas povečevala, dokler se zaradi boljšega izkoristka prostora ni vzpostavil nov model širjenja in združevanja obdelovalnih površin. V nekaterih primerih imamo vtis, da je ograda dvojna. To bi

Prva parcelacija sovpada s pojavom domnevnih grobnih grobelj znotraj ovalnih ograd. Njihova gradnja morda sega v sam začetek poljedelstva pri nas, njihova opustitev pa bolj ali manj z zatonom pokopavanja v grobnih grobljah. lahko pomenilo, da je ob ogradah tekla obzidana pot, ki je lahko z ogrado sočasna ali pa kasnejša, ali pa da je ograda imela obzidan obhod.

V kontekst parcelacije ozemlja z ovalnimi polji spadajo še manjše ovalne ograde z grobljo v sredini. Domnevno gre za grobne groblje ${ }^{4}$. Ograde z grobljami imajo gotovo simboličen pomen. V kolikor bi šlo le za čiščenje polj, bi kamenje gotovo naložili v obodne zidove, saj te ograde navadno niso prav velike. Očitno je tudi, da skupine večjih ograjenih grobelj pogosto najdemo na izpostavljenih vidnih mestih, manj zanimivih za kmetijsko obdelavo. Nahajajo se na preglednih mestih, vidnih iz gradišč, ob poteh, ki vodijo gradišča, ter na zunanjih robovih obdelovalnih površin. Gotovo so tvorile nekakšno simbolno krajino. Pogosto jih je na isti lokaciji več, še posebej na prestižnejših, dobro vidnih mestih. Včasih na mestu ene zrase še druga, največkrat tako, da je starejša vključena v ogrado mlajše, da mlajša prekriva prostor starejše. Oboje kaže na dolgotrajnost prakse gradnje grobelj.

Glede na to, da vse druge oblike parcelacije groblje negirajo in vključujejo v svoje zidove, lahko domnevamo, da sta pojava parcelacije zemlje v ovalnih poljib in gradnje grobelj najstarejša in sočasna, kar bi pomenilo, da s spremembo načina pokopavanja sovpada tudi sprememba parcelacijes. Obzidanih poti pri tej obliki parcelacije verjetno ni bilo. Gotovo so bile vzpostavljene glavne prometnice, vendar niso bile posebej označene

4 »Za Kras in Istro so bili za bronasto dobo značilni pokopi v majhnih kamnitih gomilah, komaj izstopajočih iz tal (značilnih povsod za to obdobje).« Marchesettiv svojih zapiskih poroča o stotinah tovrstnih gomilv Istri in na Krasu, tudiv nekem gozdu med Šembijani (Sembie) in Knežakom (naveden nepravilno z nemškim imenom kot Graffenbrum, pravilno Graffenbrun). Po Marchesettiju jih vedno najdemo v bližini gradišč. Marchesetti je nekatere izkopal. V vseh so našli skromne grobne pridatke, nekaj kosov črepinj grobe strukture med močno razpadlimi kostmi pokojnika. Ovalne ograde niso omenjene; morda niso bile opažene. Glej Ruaro Loseri 1993 , I28. Seveda pa ni nujno, da je vsak kup kamenja grob. Lahko je samo kup kamenja.

$5 \quad$ Prehod iz prve faze parcelacije v drugo predstavlja glede na sliko v pokrajini velik prelom. Nikdar kasneje ni bila nadomeščena in predelana skoraj celotna prostorska infrastruktura. Domnevamo lahko tudi, da so s tem povezane tudi spremembe v družbi. Približno v tem času se spremeni način pokopavanja. Groblje se vključujejo v nove ograde. Večje parcele morda kažejo na drugačno obdelavo (oranje) in na večje posesti ter morda na večjo družbeno razslojenost. 
in trasirane, njihov potek pa se je verjetno spreminjal.

\section{Druga parcelacija - polja organskib oblik}

Polja, združena $v$ to skupino, so različnih oblik, skupne pa so jim nepravilne organske oblike in želja po boljšem izkoristku razpoložljive površine, brez neizkoriščenega vmesnega prostora, ki je ostajal med ovalnimi polji. Namesto stalne gradnje novih ovalnih ograd se je pričelo obstoječa polja združevati v nova, večja, najpogosteje podolgovata polja polovalnih ali nepravilnih organskih oblik. Pri tem se je pogosto uporabilo dele zidov predhodnih ovalnih polj, v mejne zidove se je vključevalo obstoječe groblje - pojav, ki je opazen tudi pri vseh kasnejših parcelacijah. Oblika novega polja je bila odvisna od reliefa, dane površine in že obstoječih polj in poti. $\mathrm{V}$ grobem jih lahko razdelimo $\mathrm{v}$ dve skupini. $\mathrm{V}$ prvi so sestavi polj, za katere se zdi, da so se predhodnemu jedru, včasih tudi večjemu ovalnemu polju, na obod dodajale nove ograde. Opaziti je težnjo po zaokrožanju posesti navzven. Polja so na zunanjem delu zaokrožena in kdaj obkrožena z obzidanimi potmi. V drugi so skupine polj, kjer pa so obliko polj v večji meri določale poti, ki so vodile iz jedra, ali pa je nagnjen teren narekoval gradnjo teras. V tem primeru so polja prevzela bolj podolgovato, iztegnjeno obliko. Kot omenjeno se pri tej obliki polj pojavi izravnavanje terena $v$ terase (slika 4 ). Novi obliki polj so verjetno botrovali naraščanje prebivalstva, večji pritisk na krajino in težnja po boljšem izkoristku prostora. $Z$ večanjem potreb so se dodajala nova in nova polja. Zdi se, da so poljske enote večje kot v prejšnji fazi. $Z$ novo obliko deljenja zemlje se izbriše vmesni prostor med ovalnimi polji. Poti dobijo stalne trase in so obzidane.

Način razdelitve zemlje s polji organskih oblik je zaobjel praktično celotno ozemlje, vsekakor so znotraj tega vsi sedanji obdelovalna zemljišča in travniki, opazen pa je tudi na območjih, ki se ali so se do prve polovice 20 . stol. uporabljala le kot pašniki in v gozdu.

6 Domnevno sovpada zželezno dobo.
Opisana oblika parcelacije je v znatni meri še vedno prisotna $\mathrm{v}$ sedanji parcelaciji zemljišč na Krasu.

\section{Tretja parcelacija - polja z ravnimi stranicami}

Za parcelacijo polj $z$ ravnimi stranicami je značilna težnja po regulaciji, dosledna uporaba ravnih in vzporednih črt pri postavljanju mejnih zidov. Pri delitvi zemlje se za izhodišče za vlečenje osnovnih črt uporablja iz terena izstopajoče poudarke (pogosto skale in kupe kamenja, tudi prazgodovinske groblje), ki se jih povezuje z ravnimi črtami, ki so lahko precej dolge in pogosto prečkajo več parcelnih enot. Pogosta je uporaba vzporednic, vzorec pa praviloma ni pravokoten, najpogosteje je tloris rombast. Pri bolj razgibani krajini sledi naravnim oblikam, včasih pa vsaj delno predhodni prazgodovinski parcelaciji, vendar $z$ ravnimi črtami $z$ več oglišči. Zelo opazna je težnja po izboljšavi in regulaciji terena. Nagnjeni tereni so razdeljeni v vzporedne terase. Dokaj pogoste so vrtače z reguliranimi pobočji in dnom. Pobočja so izravnana v ploskve, dno ima ravne stranice, katerih potek se prek vzporednic in nadaljevanja ravnih črt vklaplja v širši vzorec (slika 6). Posamezne poljske enote so praviloma precej majhne, vendar so to verjetno tudi delitve znotraj posesti oz. regulacije ali izboljšave terena, npr. terase. Ta oblika parcelacije je pokrila celotno ozemlje, njene sledi najdemo praktično povsod. Posamezni parcelacijski sklopi so - verjetno zaradi razgibanosti terena in predhodne parcelacije ter lastništev - precej omejeni, usmeritev vodilnih črt je pri vsakem drugačna.

$\mathrm{V}$ to obliko parcelacije bi po obliki spadal tudi že opisan poskus rimske državne parcelacije, centuriacije (Mlekuž 2017), tj. nove parcelacije v pravilnem rastru, ki - kot ugotavlja Mlekuž - po vsej verjetnosti na Krasu ni bila uspešna zaradi razgibanosti in zelo različne rodovitnosti ter uporabnosti terena.

7 Gre za domnevne rimske posege v prazgodovinsko krajino 

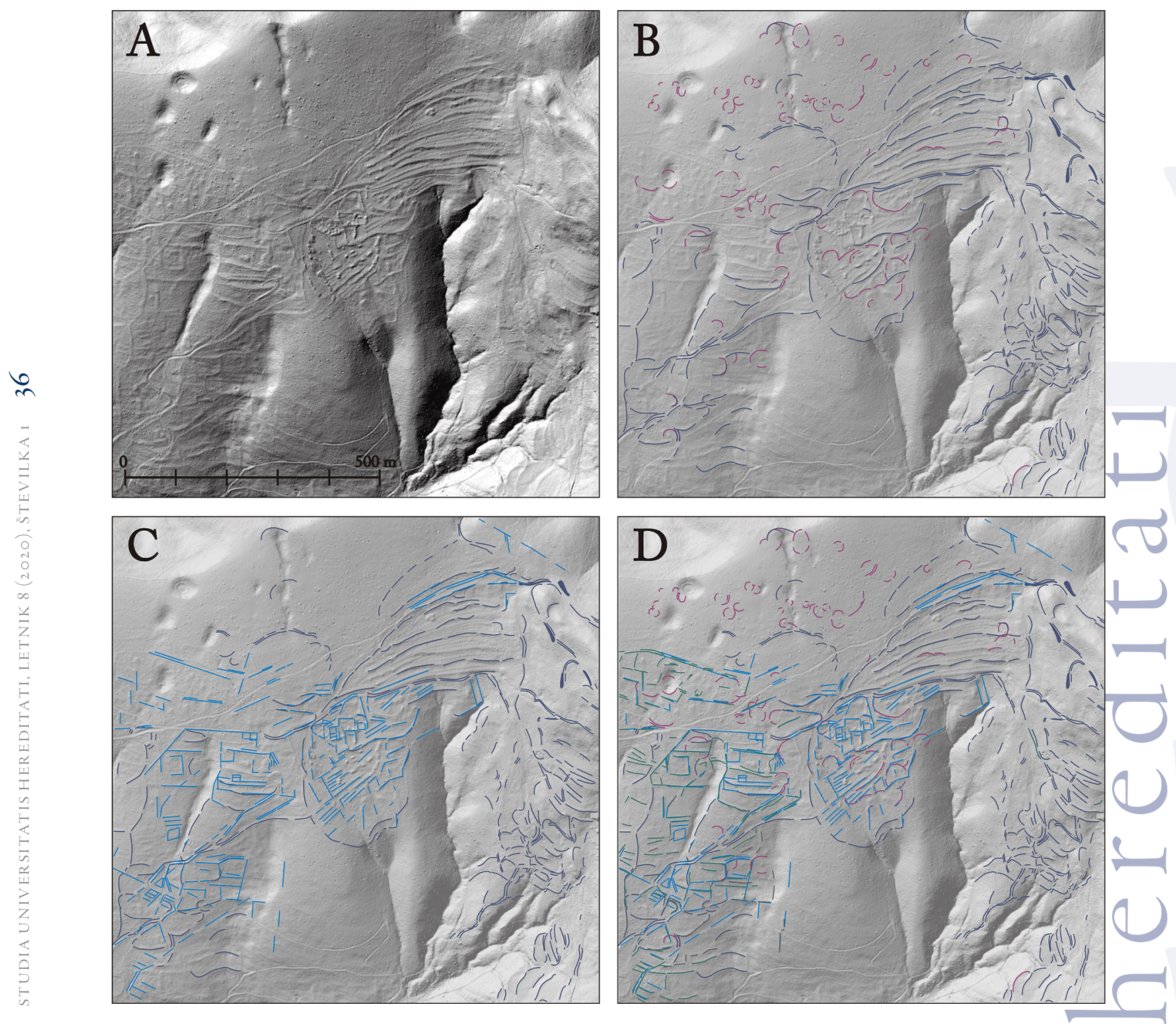

Slika 4: Izsek pokrajine z lokacijo Mandrje zahodno od gradišča Veliko gradišce pri Vrhpolju pri Hrpeljah. Na sliki 4A je posnetek lidar p, na sliki 4 B so izrisani ostanki prvih dveh faz parcelacije. Na sliki ${ }_{4} \mathrm{C}$ so izrisani prepoznani ostanki tretje faze parcelacije, polj z ravnimi stranicami. Na sliki 4D so izrisane vse štiri faze domnevne staroveške parcelacije.

\section{Četrta parcelacija - polja z nepravilnimi} stranicami $i^{8}$

Zadnja opažena oblika je bolj kot vseprisotna sistematična parcelacija, opisana $\mathrm{v}$ prejšnjih primerih, omejena na posamezne posege $\mathrm{v}$ starejši vzorec. Zanjo so - $\mathrm{v}$ primerjavi s prejšnjimi

$8 \quad$ Čas njihovega nastanka je verjetno pozna antika.
- značilni opazni masivni zidovi, ki zelo pogosto potekajo po temeljih starejših. Ker sledijo zidovom različnih oblik iz različnih predhodnih obdobij, so tudi polja, ki jih omejujejo, zelo različnih oblik. Zidovi so v pokrajini zarisani nerodno, okorno. Ovalne oblike niso povsem ovalne kot pri prvi parcelaciji, temveč nepravilne, okorne, ponekod rahlo oglate, zalomljene, ponekod 
vdrte. Isto velja za krivulje, ko sledi drugi fazi parcelacije, prav tako ravne črte niso povsem ravne, ko ta faza sledi potezam polj z ravnimi stranicami?.

$\mathrm{V}$ to skupino bi po obliki sodila tudi t. i. skatlasta polja (Mlekuž 2015, 684). Pojavljajo se predvsem na nagnjenih predelih ob nekaterih bolj odmaknjenih gradiščih. Najdemo jih tudi na lokaciji Mandrje v bližini Velikega gradišča in ob gradišču Sv. Martin pri Škrbini. Navadno proge zemlje med škarpami in zidovi, ki tečejo vzporedno s pobočjem, delijo nanje pravokotni kratki masivni zidovi, kar poljem daje značilen škatlast videz ${ }^{10}$ (slike $\left.2 \mathrm{D},{ }_{3} \mathrm{D},{ }_{7} \mathrm{C}\right)$. V to skupino bi lahko uvrstili tudi zidove, ki ponekod omejujejo bližnjo obdelovalno zemljo gradišč, kot npr. Sv. Martin pri Škrbini (slika ${ }_{7} \mathrm{C}$ ).

\section{Primeri}

Na sliki 2 je območje zahodno od gradišča Debela griža pri Volčjem Gradu. Sicer dokaj ploska površina je preluknjana s številnimi vrtačami, kaže pa številne sledove človeških posegov. Površje prekriva le malo prsti, več je je le v vrtačah. Pred pogozdovanjem in opustitvijo v 20. stol. so bili tu predvsem pašniki. V desnem spodnjem kotu so vidni okopi gradišča. Ohranjeni so številni sledovi ovalnih polj (slika $2 \mathrm{~B})$. Potek zidov pri večini od njih ni pogojen z reliefom površja. Pri nekaterih je opazna delno ohranjena dvojna ograda oziroma domnevna obhodna pot. Tiste $\mathrm{z}$ večjimi grobljami najdemo predvsem $\mathrm{v}$ bližini vijugaste obzidane poti iz druge faze parcelacije, polj organskih oblik, ki obide gradišče na

9 Iste značilnosti opazimo tudi pri sedaj aktualni parcelaciji, predvsem na bolj zakraselih in razgibanih terenih, kot npr. severno od Škrbine (slika 7).

Io Najdemo jih le na bregovih v bližini nekaterih gradišč, ki so povečini bolj odmaknjena in v hribovitem območju. Najverjetneje so poznoantičnega izvora, iz časa preseljevanja ljudstev, ko so bila gradišča ponovno obljudena. Njihovi prebivalci so se bali preveč oddaljiti od zavetja in so zato obdelovali le bližnje bregove. Ti so bili kasneje zaradi težavne obdelave verjetno ponovno opuščeni.

I I »Prazgodovinsko gradišče z obrambnim obzidjem, na severu in jugu celo dvojnim; ves obseg zunanjega nasipa meri $850 \mathrm{~m}$, notranjega $680 \mathrm{~m}$. Po sredini vodi rimska pot v smeri sever - jug. Datacija: pozna bronasta doba, železna doba, rimska doba.« Vir: Register nepremične kulturne dediščine (http://giskd6s.situla.org/giskd/).
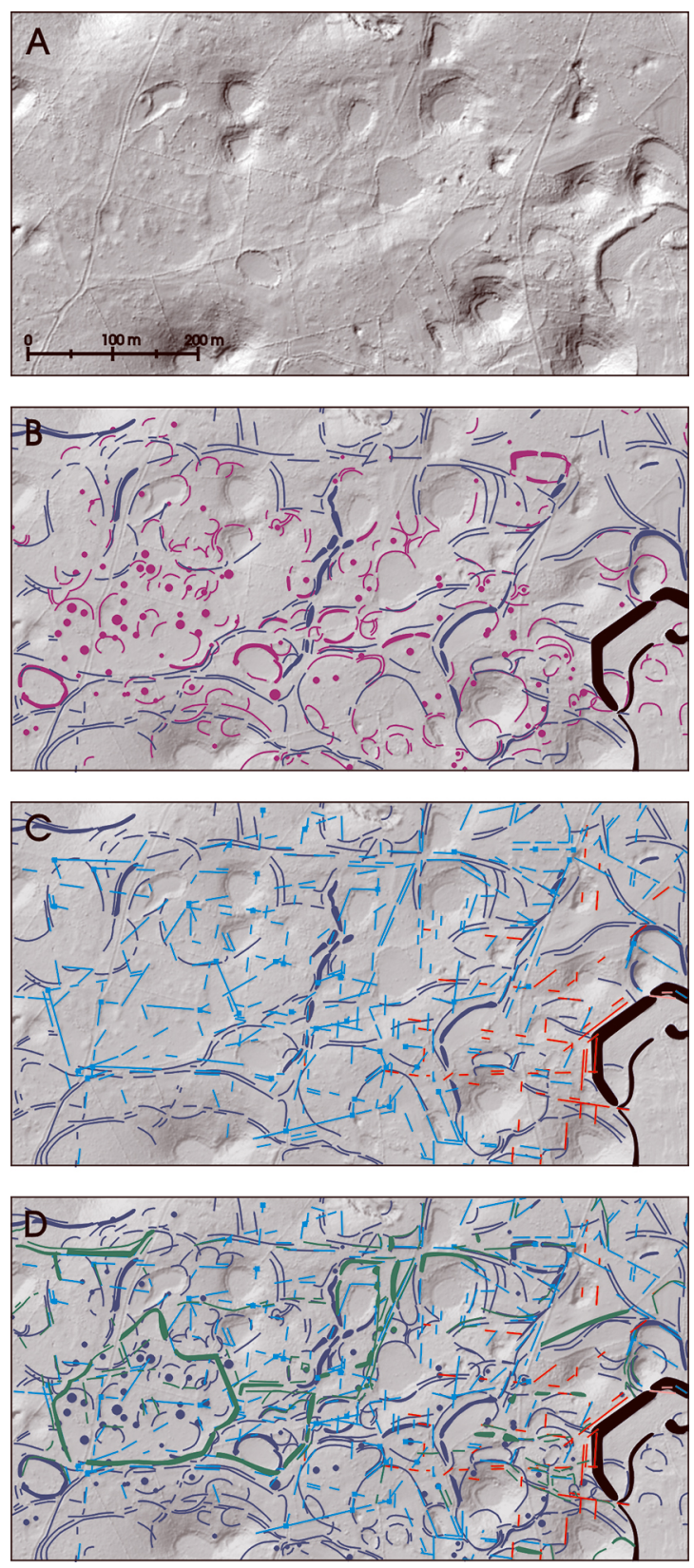

Slika 2: Izsek pokrajine zahodno od gradišča Debela griža pri Volčjem gradu. Na sliki $2 \mathrm{~A}$ je posnetek lidar, na sliki $2 \mathrm{~B}$ so izrisani ostanki prvih dveh faz parcelacije, ovalnih in organskih polj. $\mathrm{Na}$ sliki $2 \mathrm{C}$ so izrisani prepoznani ostanki tretje faze parcelacije, polj z ravnimi stranicami, zidovi, katerih potek sledi obzidju gradišča, so izrisani z rdečo. $\mathrm{Na}$ sliki 2D so izrisane vse štiri faze domnevne staroveške parcelacije. 
severu. Vidne so številne obzidane poti, predvsem v smeri vzhod - zahod, pripadajoče drugi fazi parcelacije. Te so poleg površja narekovala obliko polj druge faze. Največkrat so nepravilne ovalne in polovalne oblike ali pa zavzemajo prazen prostor med potmi. V precejšnji meri je bilo mogoče razbrati parcelacijo polj z ravnimi stranicami, ki uporablja ravne črte in vzporednice (slika 2 C). S kvadratki so označene točke, ki so služile kot izhodišča za parcelno mrežo. Opazni so deli zidov tretje faze, katerih potek se navezuje na obzidje gradišča, bodisi tako, da so z njim vzporedni, ali pa imajo za izhodišče domnevne vhode $v$ gradišče. $\mathrm{Na}$ sliki $2 \mathrm{D}$ so prikazane vse štiri faze parcelacije. Opaziti je, da zidovi četrte faze parcelacije polj z nepravilnimi stranicami sledijo potezam zidov prejšnjih faz. Še posebej je to razvidno v primeru velike masivne ograde nepravilne oblike na levi strani slike. Njeno nenavadno obliko si lahko razložimo le s prilagajanjem starejšim parcelnim mejam. Potek njenih zidov deloma sledi poteku ovalnih polj - deloma so to polja organskih oblik ter polja z ravnimi stranicami. Glede na to, da se nahaja sredi območja, ki je bilo v zadnjem obdobju namenjeno paši, je možno, da je služila kot obora za živino. V vdolbini znotraj nje bi lahko bil kal.

$\mathrm{Na}$ sliki 3 je razgibano območje severno od Povirja. Na vzpetini v levem zgornjem kotu so vidni vzhodni okopi gradišča Tabor pri Povir$j u^{12}$. Na gričih in južno od njih so opazni ostanki ovalnih ograd. Posamezni deli so vidni tudi med njivami v zgornjem levem kotu izseka. Najdemo jih tudi znotraj gradišča. Dokaj številne so groblje z ostanki ovalnih ograd, ena je vrh sosednjega Srednjega vrha jugovzhodno od gradišča. Posebno na območju $\mathrm{z}$ najboljšo obdelovalno površino (v zgornjem desnem kotu izreza) je zelo dobro ohranjena parcelacija polj organskih oblik. Povečini so nepravilne podolgovate oblike, prilagajajo se razgibanem terenu in deloma poteku

I2 》Gradišče s 3. utrjenimi vrhovi, obdanimiz enotnim obzidjem. Ob vznožju gradišča je prazg. žgano grobišče, v Gorenji jami je najdeno okostje latenskega bojevnika. Rimsko poselitev dokazujejo ostanki stavb na Strmci, srednjeveško pa stolp na Taboru . Datacija:pozna bronasta doba, železna doba, rimska doba, srednji vek.« Vir: Register nepremične kulturne dediščine (http://giskd6s.situla.org/gi$\mathrm{skd} /$ ). poti. Prav razgiban teren je bil tudi vzrok, da so se ohranila do danes, saj s svojo obliko optimalno izkoriščajo razpoložljivi prostor. V svojo mrežo vključujejo tudi ostanke ovalnih polj. Dvignjena obzidana pot, ki diagonalno prečka polje med gričema, se lepo vklaplja v vzorec in verjetno izvira iz istega časa. V fazo polj organskih oblik bi po zasnovi sodili tudi okopi gradišča (slika ${ }_{3} \mathrm{~B}$ ). Podoben vzorec poljske razdelitve je delno viden tudi drugod na obravnavanem območju. Dobro ohranjeni so tudi sledovi polj $z$ ravnimi stranica$m i$. Na severovzhodnem delu z najboljšo obdelovalno zemljo se povečini prilagajajo predhodni parcelaciji, katere posamezni deli so delno izravnani in popravljeni. Drugod je bila vzpostavljena nova parcelacija, ki je od prejšnje ohranila le potek poti. Na severovzhodnem pobočju Srednjega Vrha so opazni ostanki delno izravnanih teras, morda vinograda. Ostanke zidov, ki jih lahko uvrstimo $\mathrm{v}$ fazo polj $z$ nepravilnimi stranicami, najdemo predvsem južno od obeh vzpetin. (slika $\left.{ }_{3} \mathrm{D}\right)$.

$\mathrm{V}$ nadaljevanju poglejmo Mandrje pri Vrhpolju pri Hrpeljah (slika 4). Tu so ostanki rimske naselbine ${ }^{13}$. Lokacija se nahaja na blagem južnem pobočju grebena neposredno pod prazgodovinskim gradiščem na vrhu vzpetine, ki se po njem imenuje Veliko gradišče. V primerjavi s prejšnjima primeroma je tu teren veliko bolj »čist «, manj je bilo posegov v prostor, predvsem novoveških. Vrh grebena so opazni raztreseni ostanki ovalnih polj, številna imajo znotraj sebe groblje. Posebno v osrednjem in vzhodnem delu našega izseka so zelo lepo opazne zasnove polj organskih oblik (slika 4 B). Skupina polj na obsežnem rahlo nagnjenem platoju se združuje v zaokroženo ovaljasto obliko. Znotraj nje so vidni deli predhodnih ovalnih polj. Več vodoravno nanizanih enot morda kaže na postopno rast skupine, lahko pa je vzrok notranje razdelitve nagnjenost terena. Severovzhodno od nje je na nekoliko bolj nagnjenem terenu v terasah raz-

I3 》Staro naselbinsko območje, izpričano v izročilu, je potrjeno z obstojem antičnodobne kulturne plasti, ki jo je zaslediti na površini. Obsežne ruševinske groblje dokazujejo sistem urbane zasnove. Datacija: rimska doba.«Vir: Register nepremične kulturne dediščine (http://giskd6s.situla.org/giskd/). 

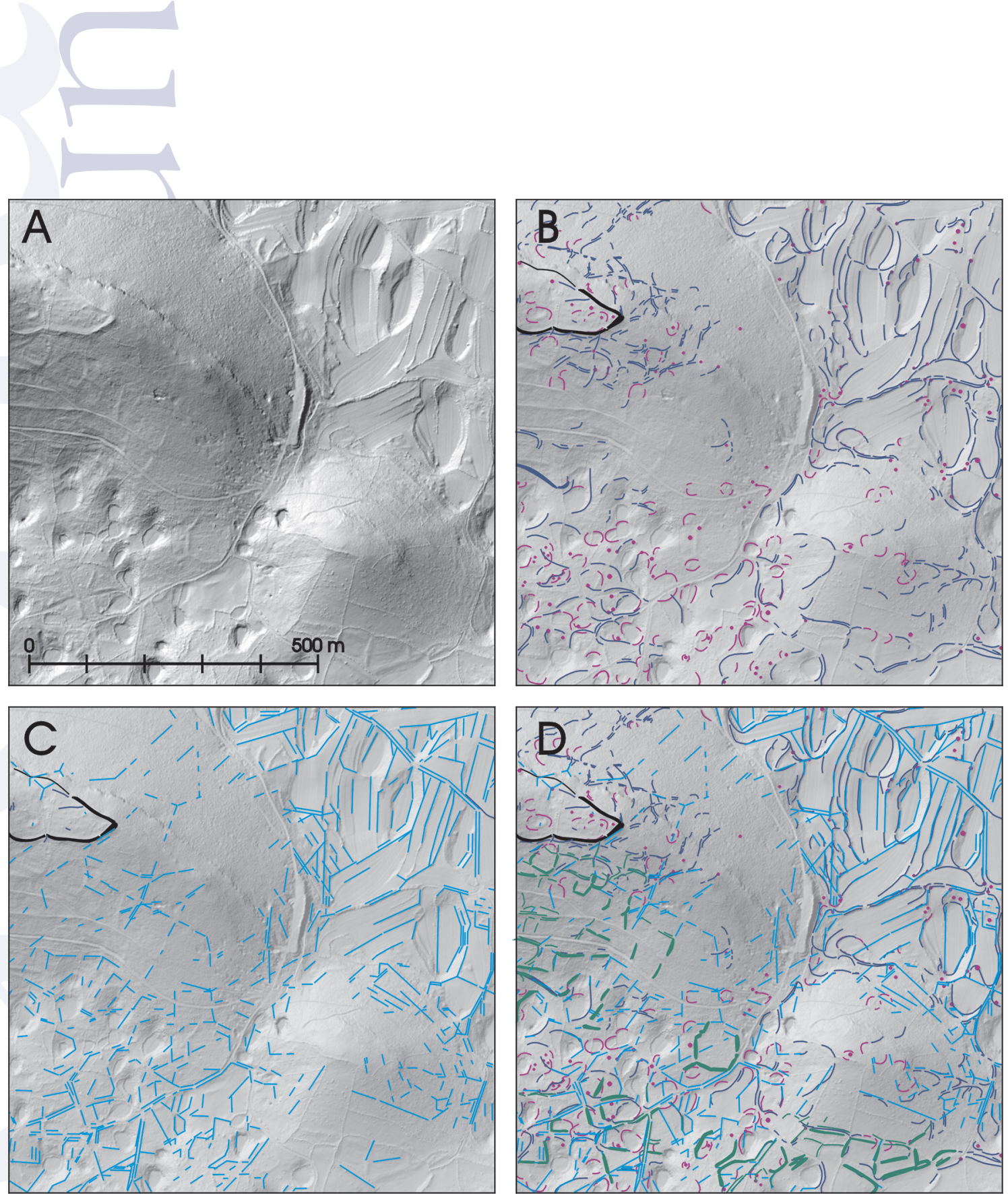

Slika 3: Izsek pokrajine vzhodno od gradišča Tabor nad Povirjem. Na sliki 3 A je posnetek lidar, na sliki 3 B so izrisani ostanki prvih dveh faz parcelacije. Na sliki ${ }_{3} \mathrm{C}$ so izrisani prepoznani ostanki tretje faze parcelacije, polj z ravnimi stranicami. Na sliki 2 D so izrisane vse štiri faze domnevne staroveške parcelacije.

porejena druga skupina polj. Nagnjen teren in ujetost med dve poti, ki vodita proti vrhu Velikega gradǐ̌ča, sta narekovala podolgovate polovalne, jezikaste oblike. Naprej proti vzhodu, na položnejši polici neposredno pod vrhom Velikega gradišča, je tretja skupina polj organskib oblik, organizirana $v$ treh nivojih. $\mathrm{Na}$ zgornjih dveh opazimo $\mathrm{v}$ delno izravnanih terasah podolgova- ta polja, po obliki podobna tistim iz predhodne skupine, vendar so manjših dimenzij zaradi omejenega prostora. Bolj razgibana je slika v obsežnejšem spodnjem platoju, kjer so prisotni ostanki starejših ovalnih polj.

Ostanke polj organskih oblik opazimo tudi zahodno od osrednjega polja, vendar tu prevladuje poznejša parcelacija. Izstopajoči nasipi $\mathrm{v}$ 

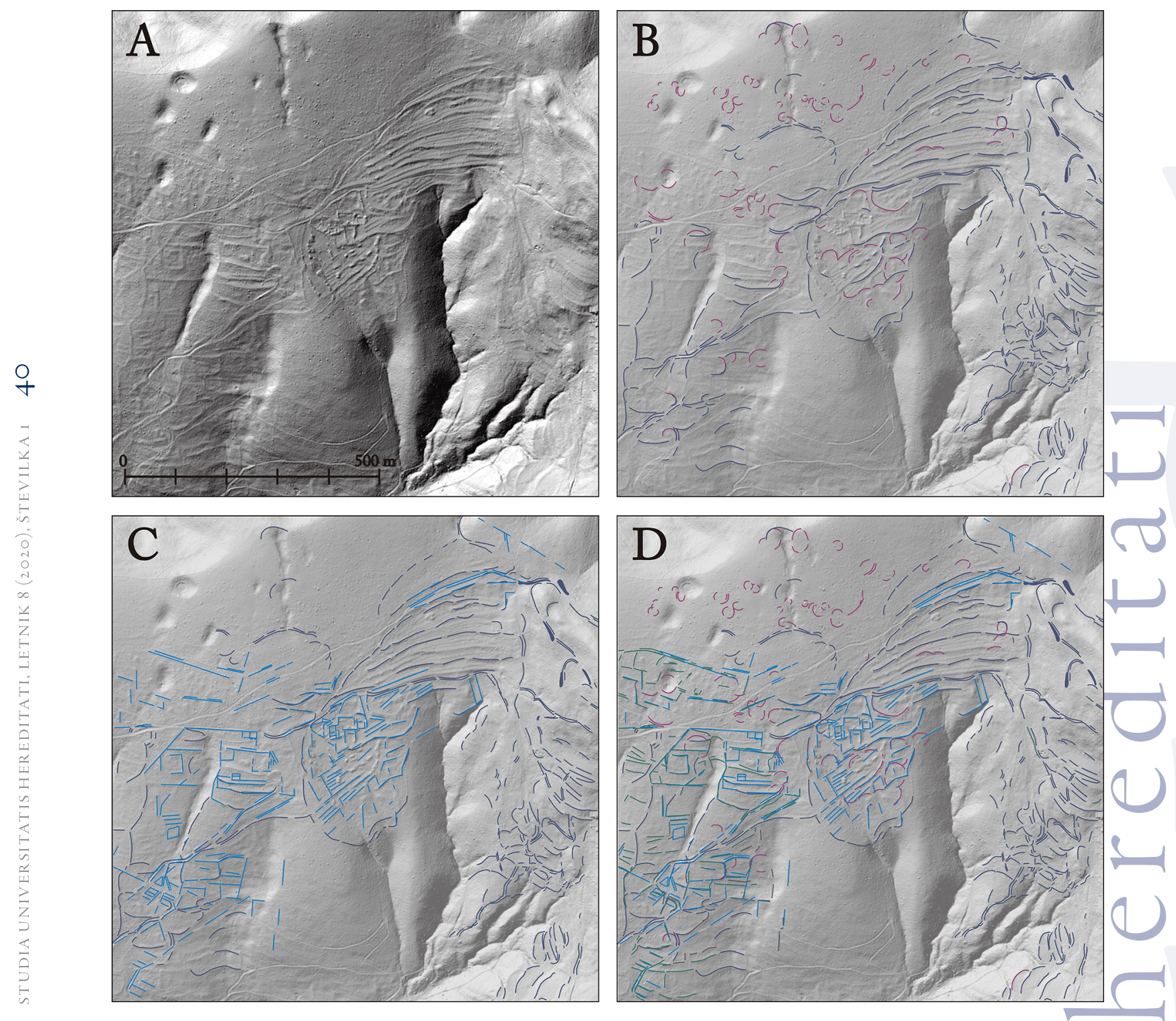

zgornjem delu osrednje skupine polj izdajajo lego antičnega naselja (slika $\left.{ }_{4} \mathrm{C}\right)$. Tu lahko opazujemo, na kakšen način je bila nova zasnova, ki sodi $\mathrm{v}$ skupino polj $z$ ravnimi stranicami, vstavljena $\mathrm{v}$ predhodno parcelacijo. Pri zasnovi, ki v osnovnih potezah sledi predhodni organizaciji prostora $^{14}$, je opazna dosledna uporaba ravnih črt. Kjer je le možno, so bile tako pri zasnovi objektov kot tudi zasnovi okolice uporabljene vzporednice. Ravne črte in vzporednice se prenašajo

tudi na večje razdalje, kar izdaja enotno zasnovo naselbinskega kompleksa in okoliške obdelovalne zemlje. Ureditev z ravnimi vzporednimi črtami je zelo prisotna na osrednjem polju ter proti vzhodu pod skupino podolgovatih organskih polj, znotraj katerih pa je ni opaziti. Zelo opazna je na zahodni strani našega izseka, manj pa severno, na slabšem terenu proti vrhu grebena. Enotna zasnova daje misliti, da gre za posest enega lastnika - $\mathrm{z}$ villo rustico $\mathrm{v}$ zgornjem delu osrednjega polja, okoli katere je parcelacijska mre- 
vah poti in domačij, ki pogosto oklepajo obode zaobljenih stavbnih parcel, domnevno dele nekdanjih ovalnih polj. Opazni so tudi deli zidov, ki se sedaj lahko nahajajo znotraj novejših večjih parcel, zarisujejo pa oblike, značilne za domnevno staroveško parcelacijo. Vtis je, da so sedanje vasi in domačije $\mathrm{e}^{15}$ vstavljene $\mathrm{v}$ starejšo parcelno mrežo. Pri njihovi gradnji in zasnovi so se prilagajale starejšim danostim, tako parcelaciji kot reliefu, ki nista bila bistveno spremenjena. Očitno je tudi, da se parcelni vzorec na območjih vasi razlikuje od tistega na drugih površinah. Površine parcel so manjše, znotraj vasi prevladujejo obrisi parcel, ki so značilni za prvo parcelacijo ovalnih polj. Njihova izvorna namembnost verjetno ni bila obdelovalna zemlja, saj se kraške vasi navadno nahajajo na bolj skalnatem terenu. Če pogledamo natančneje, opazimo, da $\mathrm{v}$ središču posameznih obdelovalnih površin niso gradišča, temveč mesta sedanjih vasi ${ }^{16}$. Vasi same so zasnovane kot vozlišče poti, po katerih se dostopa do okoliških obdelovalnih površin. Najverjetnejše se zdi, da so bile na njihovih mestih že izvorno enote, okrog katerih se je vrtela kmetijska dejavnost. Po tem lahko sklepamo, da so bile ovalne ograde uporabljane znotraj naselij tudi $\mathrm{v}$ kasnejših dobah, kar morda potrjujejo tudi sledovi ovalnih ograd znotraj gradišč. Na naših primerih je to opazno na gradišču Tabor nad Povirjem in Debeli griži pri Volčjem gradu (sliki 2 in 3 ).

Ostanki parcelacij pa so opazni tudi na površinah, ki so se v novem veku uporabljale le kot pašniki. Njihov raster postane jasen šele z označevanjem in izrisovanjem posameznih sledi. Parcelacija je na teh področjih povečini komaj opazna, pogosto jo najdemo na prisojnih pobočjih kraških vrtač in vzpetin. Te so prepredene s komaj vidnimi potmi, ki potekajo med posameznimi enotami, so različnih oblik, spadajo pa v katero od zgornjih oblik polj (slika 6). Vseeno pa so enote največkrat štirikotne z lastnostmi polj $z$ ravnimi stranicami. Pobočja so pogosto delno

I5 Katerih osnovna enota je štirikotnik. Nizi štirikotnih objektov se prilagajajo zunanjim mejam stavbnih parcel, ki so pogosto zakrivljene.

I6 Gradišča so pogosto na odmaknjenih visokih legah, odmaknjena od obdelovalne zemlje in vsaka vas nima gradišče v bližini. izravnana, predvsem v vrtačah, kjer so površine manjše (slika $6 \mathrm{~B}$ ), in razdeljena $\mathrm{v}$ nagnjene terase oziroma ploskve, ki jih delijo izravnane vodoravne poti, ki praviloma tečejo vzporedno. Navpične povezave na strmejših terenih potekajo postrani glede na pobočje - $s$ tem so se načrtovalci izognili prestrmim vzponom. Enote so praviloma manjših mer. Verjetno ne gre vedno za posamezne samostojne parcele, poti imajo lahko le vlogo dostopa do posameznih delov kompleksa. Površino večinoma prekriva tanka plast prsti, ki ni povsod enakomerna, ponekod je ujeta le v žepe med skalami. Iz nje štrlijo kamni in skale, zaradi česar je primerna la za ročno-motično obdelavo. Ker so to prisojna pobočja, verjetno pridejo v poštev predvsem sredozemske kulturne rastline, ki potrebujejo več sonca in manj vode npr. fige, oljke in predvsem trta. Teren se povsem ujema z opisom Plinija starejšega, ki govori o pridelavi slovečega pucinskega vina, ki se je pridobivalo na »saxoso colle « (kamnitem griču), »vina pucina in saxo conquutur « (vina pucina se kuhajo v kamnu), pridelava pa je bila količinsko skromna. Opisuje tudi za trte blagodejni vpliv mor$\mathrm{ja}^{17}$ (Panjek 2015).

Ostanki te parcelacije so močno razširjeni vsepovsod, predvsem pa po prisojnih pobočjih vrtač in vzpetin. Poglejmo na primer pobočja vrtače Borečnik vzhodno od vasi Rubije pri Komnu. V novejšem času neobdelana, strma, prisojna pobočja vrtače (slika $6 \mathrm{~A}$ ) so izravnana in oblikovana $\mathrm{v}$ rombaste ter trapezaste ploskve. Opazne so vodoravne poti in dve navpični, ki sta potekali po dveh vzporednih poševnih nasipih. Najverjetneje je bil tu vinograd. $Z$ ravnimi stranicami je zamejeno tudi dno vrtače. Položno zahodno pobočje je razdeljeno v vzporedne njivske terase, ki so bile še do pred kratkim obdelane. $\mathrm{Na}$ okroglastem kuclju ${ }^{18}$ sredi pobočja so opazne izbokline $\mathrm{v}$ terenu in trapezasta zasnova, morda ostanki rimske ville rustice.

Kot drugi primer poglejmo položno prisojno pobočje severno od vasi Mali dol pri Komnu. Opazni so sledovi prvih treh parcelacij. Najob-

\footnotetext{
i7 Tavokolico Komna prihaja po Brestoviški dolini.

i Katerega oblika morda izhaja iz starejših obdobij.
} 

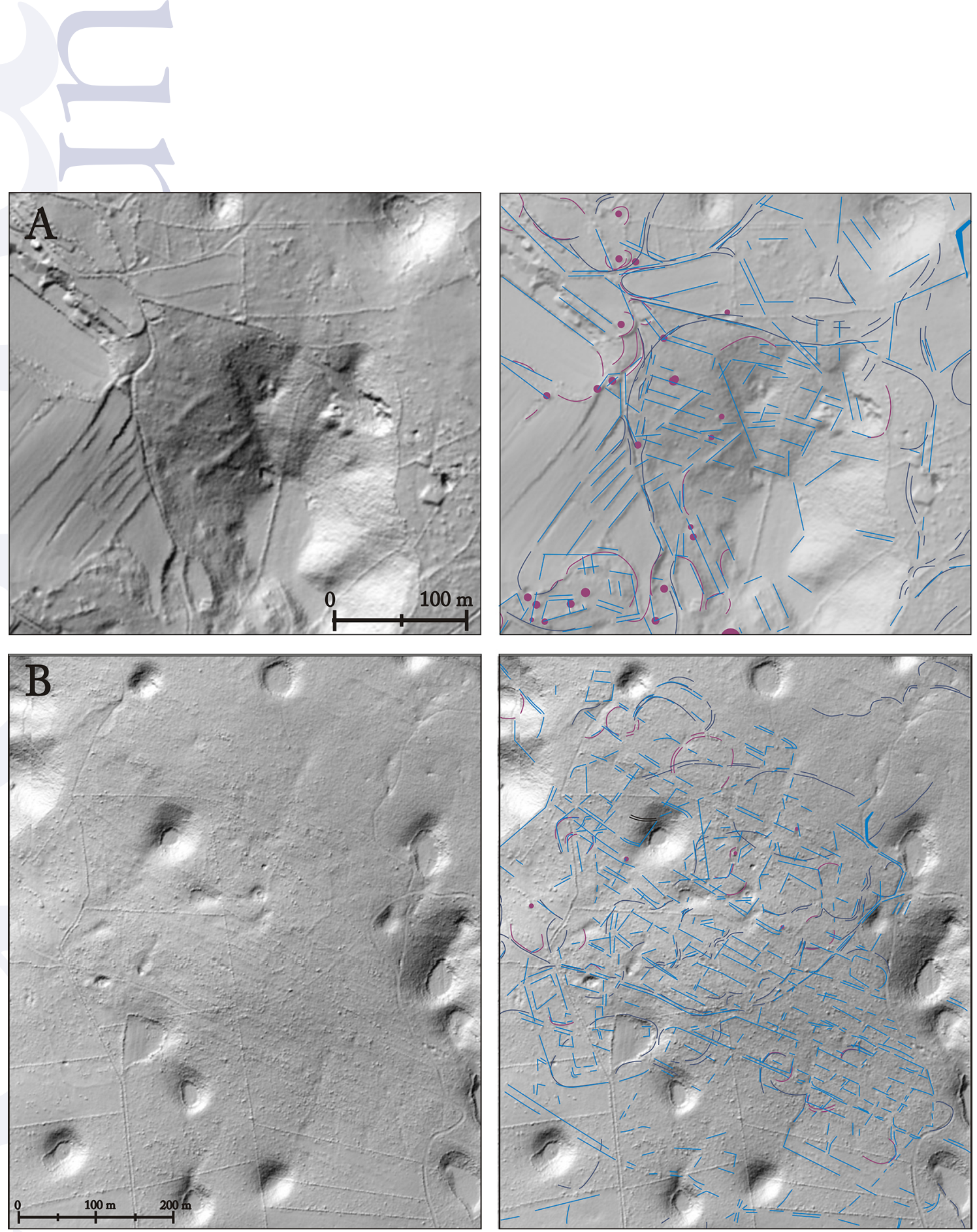

Slika 6: Zgoraj: vrtača vzhodno ob vasi Rubije. Preko posnetka na desni so vrisane prve tri faze staroveške parcelacije. Spodaj je izsek položnega pobočja severno od vasi Mali dol pri Komnu. Preko posnetka na desni so vrisane prve tri faze staroveške parcelacije. Že na prvi pogled preseneča nenavadna pravilnost in vzporednost plastnic.

sežnejša je parcelacija polj z ravnimi stranicami. Poleg plastnic, za katere zaradi vzporednosti lahko domnevamo, da so bile vsaj delno regulirane, opazimo še vodoravne nasipe, po katerih so vodile poti, ter sesute zidove, morda škarpe. Opa- zne so tudi poševne poti. Nekatere poti sledijo poteku starejših poti iz faze polj organskih oblik. Sodoben mejni zid ${ }^{19}$, ki diagonalno prečka po-

19 Gre za parcelacijo iz 19. stoletja, ko so bila razprodana in razdeljena nekdanja skupna zemljišča. Zanjo so značilni zidovi v ravnih črtah, vendar delitev ni tako sistematična kot pri poljih $z$ ravnimi 
bočje, vsaj deloma sledi parcelaciji polj $z$ ravnimi stranicami. Sledi na ravnini kažejo na drugačno razdelitev zemlje in $s$ tem na drugačno rabo prostora.

Za konec poglejmo še območje severno od vasi Škrbina med gradiščema Lipovnik $^{2 \circ}$ in Sv. Martin ${ }^{21}$ (slika 7). Gradišče Lipovnik skrajno levo zgoraj tvorita dva utrjena vrhova, ki sta nadzorovala poti prek dveh prelazov. Na zahodnem vrhu, Sv. Katarini, je opazen oval $25 \times 20$ m. Tudi Lipounik oklepa obzidje, vendar po količini razvaline obzidja izgleda, da to ni bilo v celoti dokončano - oziroma le na njegovi vzhodni strani, ki je obrnjena proti prelazu Škapce in Vipavski dolini, kjer so znotraj obzidja nepravilne ovalne zasnove tudi otrebljena površina in urejene terase. Oba vrhova je na severni strani povezoval zid, južno stran pa varuje naravni prelom. Med vrhoma so opazne terase in ograde, v vrtači na sredini pa je bila verjetno urejena lokev ali kal. Sledi na grebenu nakazujejo na dolgo poseljenost. Po sledovih ograd lahko sklepamo, da je bilo tu verjetno pastirsko naselje, na obeh vrhovih pa sta bili verjetno manjši utrjeni postojanki, ki sta nadzorovali prelaze, v celoti pa je kompleks verjetno služil kot občasna utrdba. Glede na ostanke domnevnega vinogradniškega kompleksa (slika ${ }_{7} \mathrm{C}$ ), ki sega tudi izven obsega nekdanjega gradišča, so bili v antiki verjetno tu zasajeni vinogradi. Na zahodnem delu istega niza vzpetin, na izstopajočem osamelcu, najdemo gradišče Sv. Martin nad Škrbino. Lega je zagotavljala izvrsten pregled nad tem delom Krasa in dobro zavarovanost. Notranje je razdeljeno na akropolo na nepravilnem ovalnem platoju okoli skalnate-

stranicami.

20 »Obsežno prazgodovinsko gradišče z monumentalnim obrambnim okopom in dobro ohranjeno kulturno plastjo. $\mathrm{Na}$ zahodnem robu gradišča so ruševine romanske cerkvice sv. Katarine, omenjane v vizitacijskih popisih med 1. I650-1750. Datacija prazgodovina, visoki srednji vek, tretja četrtina 17. stol., 1650.« Vir: Register nepremične kulturne dediščine (http:// giskd6s.situla.org/giskd/)-

2 I $\gg$ Prazgodovinsko gradišče z dobro ohranjenim obrambnim okopom. Na njegovem jugozahodnem robu so ruševine verjetno romanske cerkve sv. Martina in neke poznosrednjeveške utrdbe. Cerkev je omenjana v vizitacijskih popisih med l. 1570-1750. Datacija prazgodovina, pozni srednji vek, tretja četrtina i6. stol., 1570.« Vir: Register nepremične kulturne dediščine (http:// giskd6s.situla.org/giskd/) ga vrha in spodnje naselje na položnem severnem pobočju. Na vzpetini Mali Ovčnjak ${ }^{22}$, med gradiščema, sta dve prazgodovinski groblji, domnevno stolpa, del obrambnega sistema iz 6. stol. pr. n. št. (Teržan in Turk 2005). V spodnjem delu je v rumeni barvi nakazan del vasi Škrbina, severozahodno od $S v$. Martina, ob večjem polju, pa nekdanji zaselek Mihajli, ki je bil opuščen po požigu v drugi svetovni vojni. Prikazano ozemlje lahko razdelimo na tri dele. Spodaj v dolini je najboljša obdelovalna zemlja, višje na bolj zakraseli polici so manj kvalitetne površine, kjer so bile do 20. stoletja njive, travniki in pašniki. Strma južna pobočja hribov so se do 20 . stoletja uporabljala predvsem kot skupni pašniki v vasi Škrbina.

Vse štiri oblike parcelacije so vidne po skoraj celotnem izrezu. Na sliki ${ }_{7} \mathrm{~B}$ sta prikazani prvi dve obliki parcelacije. Opazne so večje koncentracije grobelj na Malem vrhu zahodno od Mihajlov, na polici pod Lipovnikom in med Škrbino in $S v$. Martinom. Delno so vidne obzidane poti, ki po obliki sodijo v fazo organskih polj in vodijo od Škrbine proti severu - prelazu Škapce, Lipovniku in Sv. Martinu ter od Sv. Martina proti zahodu in severu.

$\mathrm{Na}$ sliki ${ }_{7} \mathrm{C}$ sta prikazani parcelaciji polj $z$ ravnimi stranicami in polj $z$ nepravilnimi stranicami. Tretjo fazo je opaziti na vseh treh delih prikazanega ozemlja. V posameznih potezah je prepoznavna tudi znotraj sedanje parcelacije. Sicer slabo vidni sledovi na pobočjih hribov kažejo iste vzorce, kot smo jih opazovali na prejšnji sliki. Vidni so vzporedne vodoravne delitve (poti, nasipi in plastnice), navpične delitve posameznih parcelnih sklopov ter deli širših poti, ki vodoravno prečkajo pobočja. Kot smo opazili že pri gradišču Debela griža (slika 2), tudi pri Sv. Martinu parcelacija polj z ravnimi stranicami sledi posameznim odsekom obzidja. Pod gradiščem so lepo vidna škatlasta polja, ki sledijo usmerjenosti polj z ravnimi stranicami. Lepo viden je tudi masiven zid, ki z jugozahodne strani oklepa bližnjo obdelovalno zemljo, pripadajo-

\footnotetext{
22 》De kamniti prazgodovinski gomili, od katerih je tista na koti 385 večja in v celoti ohranjena, druga je delno poškodovana. Verjetno prekrivata obrambna stolpa. Datacija: železna doba«. Vir: Register nepremične kulturne dediščine (http://giskd6s.situla.org/giskd/)-
} 

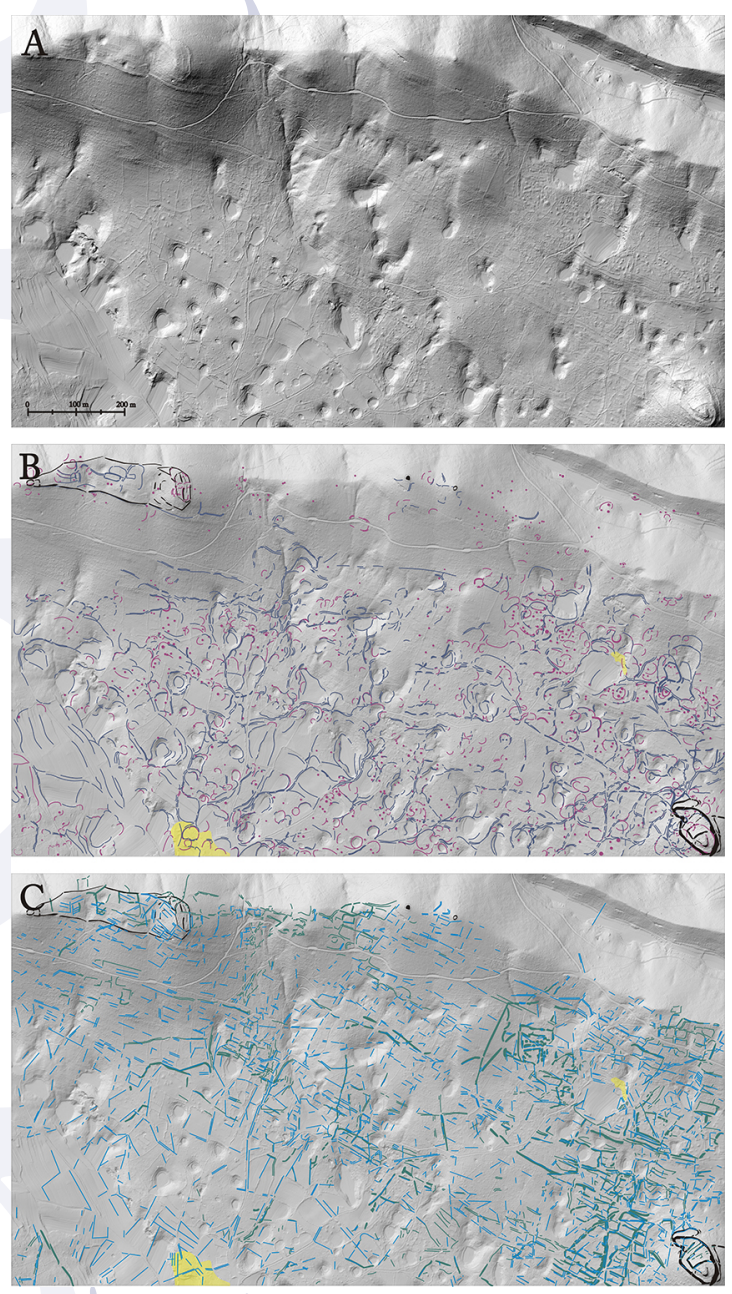

Slika 7: Izsek s prisojnimi pobočji med gradiščema Lipovnik (zgoraj levo) in Sv. Martin (spodaj desno). Z rumeno sta označeni legi naselij Škrbina (spodaj) in nekdanjega zaselka Mihajli. Na sliki 7 A je lidar posnetek, na sliki 7 B so izrisani ostanki prvih dveh faz parcelacije. Na sliki $7 \mathrm{C}$ so izrisani prepoznani ostanki tretje faze parcelacije, polj z ravnimi stranicami in polj z nepravilnimi stranicami.

čo gradišču. Glede na to, da v nekaterih potezah sledi mejam polj z ravnimi stranicami, verjetno tako kot škatlasta polja spada v zadnjo skupino polj z nepravilnimi stranicami. Poleg že omenjene velike koncentracije grobelj opazimo na Malem vrhu še obsežne nasipe in jarek. Lokacije ni mogoče zadovoljivo razložiti. Glede na velike kupe kamenja in vanje vloženo delo kaže na večji pomen. Glede na podobno lego glede na razmer- je z bližnjim gradiščem, kot jo imata že omenjena ograda pri Debeli griži (slika 2) in obora Šance pri gradišču Tabor pri Vrabčah (Mlekuž 2oIs, 684-686), pa lahko predpostavljamo podobno namembnost. Območje prvotnega elitnega grobišča (na vseh treh lokacijah je večja koncentracija grobelj) in verjetno svetega kraja je bilo kasneje uporabljeno za oboro za živino. Vse tri lokacije so na vzpetini v bližini gradišča in na robu obdelovalne zemlje. V primeru Malega vrha je grobelj več in nasipi zidov niso tako jasno razvidni. Morda so bili kasneje razrušeni, njihovo kamenje pa zloženo v groblje.

\section{Zaključek}

Kot je bilo že ugotovljeno (Mlekuž 2015, 2017), imamo na Krasu ohranjeno edinstveno prazgodovinsko in antično kulturno krajino, ki pa je vsaj v posameznih potezah prepoznavna povsod in ne samo na obrobnih zapuščenih območjih. Predstavlja osnovno ogrodje sedanje prostorske razdelitve, njen temelj. Prepoznamo jo po značilnih oblikah, vzorcih, modelih deljenja in oblikovanja kulturne krajine. Sledovi parcelacij kažejo, da imamo opraviti s številčno ${ }^{23}$, celovito in dobro organizirano poljedelsko civilizacijo, ki je z oblikovanjem obdelovalnih površin in kulturne krajine opravila »kiklopsko《 delo. Lahko rečemo, da jo je organizirala in simbolno osmislila. Šla je skozi več razvojnih stanj. Njena dediščina je zelo opazna še danes. Glede na to, da oblike staroveških parcelacij prepoznavamo vsepovsod, se zdi, da smo po njej podedovali osnovno mrežo naselij, poti in obdelovalnih površin ${ }^{24}$.

Zanimivo je, da so na področjih ob robu obdelovalnih površin prepoznavnejše sledi iz preteklosti, različne oblike parcelacij se med seboj prekrivajo, v manjši meri pa opažamo soobstoj

23 Kras naj bi bilvželezni dobi najgosteje poseljena pokrajina sedanje Slovenije (Bratina 2017). Takrat je bil verjetno opravljen največji vložek v krajino in v prostorsko infrastrukturo.

24 Kot kaže, drži spoznanje, da so »skupnosti pozne prazgodovinske dobe v kraškem prostoru vzpostavile stabilne strukture prostorske organizacije in izrabe prostora in da so razvile kulturne obrazce, ki bodo v dolgem trajanju prepoznavni kot značilni za to regijo «,, in da je na $\gg$ Krasu zaradi omejenosti obdelovalne zemlje in potrebnega velikega vložka odločilna dostopnost in uporabnost infrastrukture « (Slapšak 2003). 
elementov parcelacij iz različnih obdobij. To velja tako za sedanjo kot za prejšnje oblike parcela$\mathrm{cij}^{25}$. Na najboljši zemlji v bližini naselij se zdijo meje parcel stabilnejše, prisoten je soobstoj posegov iz različnih obdobij, kar se v današnji parcelaciji kaže kot nekakšna sinteza. To razliko si lahko razložimo tako, da je bila zemlja v bližini vasi vedno obdelovana (površine so bile boljše, vanje je bilo vloženega več dela), medtem ko sta se namembnost in lastništvo na bolj odmaknjenih področjih spreminjala, verjetno je prihajalo do valov obdelovanja in opuščanja in s tem do venomer novih parcel ter oblik parcelacije ${ }^{26}$.

V prvi fazi ovalnih polj, ki morda sega v sam začetek poljedelstva, so se gradila posamezna manjša ovalna ograjena polja. Ta so bila posejana po celotnem ozemlju. Obzidanih poti verjetno ni bilo, vile so se med polji. Mrtve so pokopavali pod kamnitimi gomilami, obkroženimi z ovalnimi ogradami, nekatere so imele morda obzidan obhod. Tej je sledila faza večjih polj organskih oblik, ki je v primerjavi s prvo učinkoviteje in bolj organizirano izrabljala dane površine. Poti dobijo stalne trase, so obzidane, parcelne enote postanejo večje. Površine skupnega prostora se zmanjšajo, več je obzidanih, zasebnih površin. Razvidna je močno prisotna reorganizacija prostora iz časa polj $z$ ravnimi stranicami, domnevno rimske faze parcelacije. Če ne prej, je bila v tej fazi skoraj vsaka ped zemlje razdeljena in tako ali drugače obdelana. Glavna kmetijska panoga se zdi poljedelstvo, njen obseg je bil skozi prve tri faze parcelacije v porastu na škodo reje živali. Do viška tega razvoja pride v obdobju polj z ravnimi stranicami, ko ena glavnih kmetijskih panog postane vinogradništvo z obsežnimi vinogradi ${ }^{27}$, s katerimi so bila - če je naše razumevanje pravilno - zasajena praktično vsa prisojna pobočja. Omejene posege iz faze polj z nepravilnimi stranicami in masivnimi zidovi okoli polj ob gradiščih (slika 7) pa bi lahko razumeli kot krčenje obdelovalnih površin. Obzidana je bila

25 Zadnja je bila izvedena v i9. stoletju, ko je bila razprodana skupna zemlja, predvsem pašniki (Panjek 2015, 51-52).

26 Kar morda kaže na demografska nihanja.

27 Morda tudi zaradi izločenosti staroselskega prebivalstva iz trgovine (Slapšak, B. 2003) samo najbližja obdelovalna zemlja, polja in vinogradi za zidovi so bili opuščeni in spremenjeni v pašnike.

Predlagani poskus interpretacije želi biti $\mathrm{v}$ pomoč pri prepoznavanju oblik in določanju starosti posegov v prostor. Ni nujno, da so predstavljene trditve pravilne. So opažanja in poskus interpretacije, za katero se bo še pokazalo, ali je pravilna. Potrebno bo še dodatno preverjanje, verjetno tudi reinterpretacija, ter nadaljnja poglobitev v problematiko. Za boljše razumevanje posameznega ožjega prostora bi bilo posledično treba bolje preučiti posamezne lokalne strukture, za širšo sliko pa preučiti tudi širši prostor.

\section{Povzetek}

Prispevek predstavlja analizo posnetkov zračnega laserskega skeniranja z območja slovenskega Krasa. Opravljena je bila analiza ostankov starih parcelacij, domnevno prazgodovinskih in antičnih. Glede na obliko so bile razvrščene v štiri skupine, ki so bile glede na primerjave in predviden logičen potek tudi časovno razporejene:

$$
\begin{aligned}
& \text { - } \\
& \text { - } . \text { parcelacija - ovalna polja, } \\
& \text { - } \quad \text { 2.parcelacija - polja organskih oblik, } \\
& \text { - } \quad \text { 3.parcelacija - polja z ravnimi stranicami } \\
& \text { - } \quad \text { 4.parcelacija - polja z nepravilnimi stranicami. }
\end{aligned}
$$

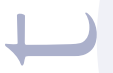

Za ovalna polja se predvideva, da so bila v uporabi od začetkov poljedelstva in do pojava žganih grobov. $\mathrm{Za}$ polja nepravilnih organskih oblik se predvideva nastanek v železni dobi. Polja z ravnimi stranicami, ki dosledno uporabljajo ravne črte in vzporedne črte, pa se uvršča v rimski čas. V to skupino sodijo obsežna oblikovana pobočja na prisojnih bregovih z ostanki poti in teras, za katere se domneva, da so ostanki vinogradov. Za polja z nepravilnimi stranicami se zdi, da so bila v uporabi v pozni antiki. Vse oblike parcelacije so bile ugotovljene na celotnem obravnavanem ozemlju, pri čemer se kaže zanimiva razlika med območjem v bližini vasi, kjer so v sklopu sedanje parcelacije ohranjeni ostanki starejših oblik, in širšo okolico, kjer se oblike parcelacij povečini »prekrivajo « v ločenih slojih, kar bi lahko kazalo na valove obdelave in opuščanja. Opažen je bil soobstoj oblik 
parcelacij - doslej še ni bilo dobe, ki bi zbrisala vse predhodne sledove.

\section{Summary}

The paper contains an analysis and interpretation of $\mathrm{Li}$ DAR images and data showing the area in the Slovene Karst region. The starting point for my research were the already known prehistoric settlements. An analysis was carried out of the remains of historic field divisions which could date back to prehistory and antiquity. They have been divided into 4 chronologically sequenced groups (according to what can reasonably be assumed) based on their shape:

$$
\begin{array}{ll}
- & i^{\text {it }} \text { field division - oval fields } \\
- & 2^{\text {nd }} \text { field divioin - organically shaped fields } \\
- & 3^{\text {rd }} \text { field division - fields with straight sides } \\
- & 4^{\text {th }} \text { field division - fields with irregular sides. }
\end{array}
$$

It is most probable that the occurence of oval fields coincided with the onset of agriculture and cremation burials. Organically shaped fields could have first occured during the Iron Age whereas fields w ith straight sides that all contain straight parallel lines probably date from Ancient Rome. Fields with irregular sides were probably in use in late antiquity. All four division methods appear throughout the area. An interesting difference can be observed between areas close to villages, where the present division still contains lines of older shapes, and the periphery where individual divisions are for the most part separately 'layered' on top of each other. This phenomenon could point at different waves of land cultivation and its abandonment in a given area.

\section{Viri in literatura}

Bernardini, F., G. Vinci, J. Horvat, A. De Min, E. Forte, S. Furlani, D. Lenaz, M. Pipan, W. Zhao, A. Sgambati, M. Potleca, R. Micheli, A. Fragiacomo in C. Tuniz. 2015. »Early Roman Military Fortifications and the Origin of Trieste (Italy).«Proc. Natl. Acad. Sci. II2 (13): 1520-29.

Betic, A., F. Bernardini in M. Montagnari Kokelj. 2008. »I castellieri di Trieste tra Carso e mare.«Karnia, Terre di Mare: L'Archeologia dei Paesaggi Costieri e le Variazioni Climatiche, ur. Rita Auriemma,
25-37. Trst; Piran: Università degli Studi di Trieste; Pomorski muzej - Museo del mare $\gg$ Sergej Mašera«.

Bratina, P. 2018. »Gradišča Krasa.« Gradišča $v$ zahodni in osrednji Sloveniji, ur. Dejan Vončina, 91-ıor. Gorjansko: Zavod Krasen Kras

Fabec, T. 20I2. » Geoarheološke lastnosti zapolnitve vrtač na Divaškem Krasu (Jugozahodna Slovenija).«V Dolgoročne spremembe okolja I, Opera instituti archaeologici sloveniae 25, ur. M. Andrič, 43-54. Ljubljana: Založba ZRC.

Flego, S., in L. Rupel. 1993. Prazgodovinska gradišca tržaške pokrajine. Trst: Založništvo tržaškega tiska, d. d.

Laharnar, B. 2013. »The Roman Stronghold at Nadleški hrib, Notranjska Region.« Arheološki vestnik 64 (I): 123-47.

Laharnar, B. 2018. »Gradišča med Nanosom in Snežnikom.« V Gradišča v zahodni in osrednji Sloveniji, ur. D. Vončina, 26-47. Gorjansko: Zavod Krasen Kras.

Lozić, E. 2016a. Arheološka interpretacija lidarskih podatkov za območje Volčji Grad - Arheološko najdišče Debela griža (EŠD 836) Strokovno poročilo o delu in rezultati, strokovno poročilo. https://www. academia.edu/3722890I/Arheolos_ka_ interpretacija_lidarskih_podatkov_za_ obmoc_je_Volc_ji_Grad_Arheolos_ko_ najdis_c_e_Debela_griz_a_ES_D_836_ Strokovno_poroc_ilo_o_delu_in_ rezultatih. Google. 2018.

Lozić, E. 2016b. Arheološka interpretacija lidarskih podatkov za sirš̌e območje med

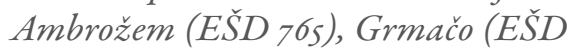
4740) in Cerkvencami (EŠD ${ }_{17658)}$ ter arheološki območji Vojščica - Tabor (EŠD 4734) in Sela na Krasu - Gradišče Podgrac (EŠD 257Io), strokovno poročilo. https:// www.academia.edu/37228949/Arheolos_ ka_interpretacija_lidarskih_podatkov_ za_s_irs_e_obmoc_je_med_Ambroz_ em_ES_D_765_Grmac_o_ES_D_4740_ in_Cerkvencami_ES_D_I7658_ 
ter_arheolos_ki_obmoc_ji_Vojs_c_ ica_-_Tabor_ES_D_4734_in_Sela_ na_Krasu_-_Gradis_c_e_Podgrac_ ES_D_25710_. Google. 2018.

Marchesetti, C. 1903. I castellieri preistorici di Trieste e della Regione Giulia. Trst: Atti Mus. Civ. Stor. Nat.

Mihovilić, K., B. Hänsel in B. Teržan. 2005. »Moncodogno. Scavi recenti e prospettive future.« V Carlo Marchesetti e i castellieri, 1903-2003: atti del Convegno internazionale di studi, Castello di Duino

(Trieste). I4-IS novembre 2003 (Fonti e studi per la storia della Venezia Giulia), ur. G. Bandelli in E. Montagnari Kokelj, $389-$ 408. Trst: Editreg.

Mlekuž, D. 20II. »Zmeda s krajinami: Lidar in prakse krajinjenja.« Arheo 28: 87-104.

Mlekuž, D. 2015. »Oblike prazgodovinske poljske razdelitve na Krasu/Shapes of Prehistoric Field Division in the Karst (Slovenia).« Kronika 63 (3): I-I6.

Mlekuž, D. 2017. »Sledovi rimske zemljiške razdelitve na Krasu/Traces of Roman Land Division on the Karst.« https:// www.academia.edu/31650010/Sledovi_ rimske_zemlji\%C5\%Arke_razdelitve_na_ Krasu_Traces_of_roman_land_division_ on the Karst.

Mlekuž, D., in M. Črešnar. 2014. »Landscape and Identity Politics of the Poštela Hillfort.« V Studia Praehistorica in Honorem Janez Dular, Opera Instituti Archaeologici Sloveniae 30, ur. S. TeccoHvala, 197-2II. Ljubljana: Založba ZRC.

Novaković, P. 2005. »The Cultural Landscape of Hillforts.« V Carlo Marchesetti e i castellieri, 1903-2003: atti del Convegno internazionale di studi, Castello di Duino (Trieste). I4-IS novembre 2003 (Fonti e studi per la storia della Venezia Giulia), ur. G. Bandelli in E. Montagnari Kokelj, 30I24. Trst: Editreg.

Panjek, A. 2015. Kulturna krajina in okolje Krasa: o rabi naravnih virov $v$ novem veku. Koper: Založba Univerze na Primorskem.
Ruaro Loseri, L. 1993. »Sepolture dell'eta' di bronzo in Carso e in Istria«: Preistoria del Caput Adriae. Ur. Cesare Russo. Videm: Istituto per enciclopedia del Friuli Venezia Giulia.

Slapšak, B.1975. »Sveto.«Varstvo spomenikov (Monuments Corservation) XVII-XIX (I): I $78-248$

Slapšak, B., 1995. »Možnosti študija poselitve v arheologiji.«Arheo 17: I-90.

Slapšak, B. 1999. »Slovenski Kras v poznejši prazgodovini in v rimski dobi.« V Kras: pokrajina, življenje, ljudje, ur. A. Kranjc, I45-63. Ljubljana: Založba ZRC.

$r$

Slapšak, B. 2003. »O koncu prazgodovinskih skupnosti na Krasu.« Arheloški vestnik 54 (I): 243-57.

Šašel Kos, M. 1999. »Promet v antiki -trgovci, vojaki in razbojniki.« V Zakladi Tisocletij, ur. B. Aubelj, 257-59. Ljubljana: Založba Modrijan.

Šašel Kos, M. 1999. »Promet v prazgodovini.« V Zakladi Tisočletij, ur. B. Aubelj, 254-56. Ljubljana: Modrijan založba:

Teržan, B., in P. Turk. 2005. »The Iron Age Tower upon Ostri vrh.«V Carlo Marchesetti e i castellieri, I903-2003 : atti del Convegno internazionale di studi, Castello di Duino (Trieste). I4-IS novembre 2003 (Fonti e studi per la storia della Venezia Giulia), ur. G. Bandelli, in E. Montagnari Kokelj, 339-53. Trst: Editreg.

Titl, J. 2006. Kraški toponimi. Koper: Založba Libris.

Vinazza, M., M. Črešnar, D. Mlekuž in B. Mušič. 2018. 》Gradišče Debela griža in možnosti neinvazivnih integriranih arheoloških raziskav.« V Gradiščav zahodni in osrednji Sloveniji, ur. D. Vončina, I03-23. Gorjansko: Zavod Krasen Kras.

Vinci, G., in F. Bernardini. 2017. $\gg$ Reconstructing the Protohistoric Landscape of Trieste Karst (North-Eastern Italy) through Airborne LiDAR Remote 
Sensing. «ournal of Archaeological Science:

Reports I2: 59I-600.

\section{Spletni viri}

Agencija RS za okolje. 2017-2019. »LIDAR.«

http://gis.arso.gov.si/evode/profile.

aspx?id=atlas_voda_Lidar@Arso,n.d., 2017-2019.

Ministrstvo za kulturo. 2017-2019. Register nepremične kulturne dediščine: franciscejski kataster. http://giskd6s.situla. org/giskd/-

Ministrstvo za kulturo. N. d. Vrhpolje pri Kozini - Arheološko najdišče Mandarje, Register nepremične kulturne dediščine http://giskd6s.situla.org/giskd/-

Udine Today. 2018. »3.000 anni fa in Friuli si beveva già il vino. $\ll$ http://www. udinetoday.it/cronaca/vino-beveva-friuli3000-anni-fa.html.

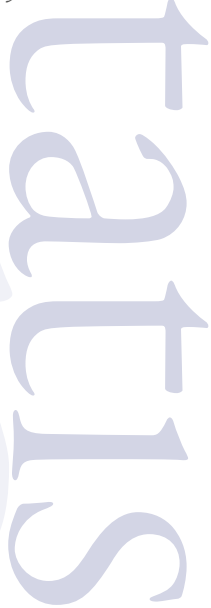

